University of Nebraska - Lincoln

DigitalCommons@University of Nebraska - Lincoln

2020

\title{
Nutrient Cycling in Forage Production Systems
}

David A. Wedin

University of Nebraska - Lincoln, dwedin1@unl.edu

Michael P. Russelle

USDA, Agricultural Research Service

Follow this and additional works at: https://digitalcommons.unl.edu/natrespapers

Part of the Natural Resources and Conservation Commons, Natural Resources Management and Policy Commons, and the Other Environmental Sciences Commons

Wedin, David A. and Russelle, Michael P., "Nutrient Cycling in Forage Production Systems" (2020). Papers in Natural Resources. 1369.

https://digitalcommons.unl.edu/natrespapers/1369

This Article is brought to you for free and open access by the Natural Resources, School of at DigitalCommons@University of Nebraska - Lincoln. It has been accepted for inclusion in Papers in Natural Resources by an authorized administrator of DigitalCommons@University of Nebraska - Lincoln. 


\title{
Chapter
}

\section{1}

\section{Nutrient Cycling in Forage Production Systems}

\author{
David A. Wedin, Professor, School of Natural Resources, University of Nebraska, \\ Lincoln, NE, USA \\ Michael P. Russelle, Soil Scientist (Retired), USDA-Agricultural Research Service, \\ St. Paul, MN, USA
}

\section{Introduction - The Systems Approach to Nutrient Cycles}

In most forage production systems, the nutrients needed for plant growth are provided by the microbially-mediated breakdown and release of plant-available mineral nutrients from dead plant tissues, livestock excreta, soil organic matter, and geochemically-bound mineral forms. Even in fertilized forage systems, determining appropriate fertilizer or manure application rates requires a "systems" approach on the part of the manager (Rotz et al. 2005; Wood et al. 2012). Fertilizer additions are simply one input in the system of inputs, outputs, pools, and fluxes that characterize nutrient cycling in a particular ecosystem.

In a systems approach, the size of the system is determined by the observer, and it is often management driven. It could be a particular field (Stout et al. 2000; Simpson et al. 2015), an entire farm (Rotz et al. 2005; Powell and Rotz 2015), a watershed (Howarth et al. 1996; Loecke et al. 2017) or, as is the case for global biogeochemical cycles, the entire earth (Smil 2000; Galloway et al. 2008). Whereas harvestable forage and livestock have traditionally been the outputs driving management decisions in forage systems, outputs of nutrients such as $\mathrm{NO}_{3}{ }^{-}$leaching, $\mathrm{N}_{2} \mathrm{O}$ gaseous emissions, and $\mathrm{P}$ run off are becoming increasingly important (Vitousek et al. 2009).
Central to nutrient cycling in any ecosystem is the concept of mass balance. Nutrient inputs must balance nutrient outputs and/or nutrient storage. Societal concerns over nutrient pollution in the environment and economic pressures on the profitability of forage systems are forcing scientists and managers to document nutrient budgets more completely and precisely (Nord and Lanyon 2003; Wood et al. 2012). The C dynamics of forage systems can be analyzed with the same "systems" approach outlined here, but are beyond the scope of this chapter (see Conant et al. 2017 for a review of grassland carbon budgets).

A nutrient cycle or budget is a network of pools (amounts) of a particular element, joined by fluxes (transfers) connecting those pools (Chapin et al. 2011). Though most elements have either a large atmospheric (e.g. C and N) or geologic (e.g. P and K) pool, the fluxes or transfer rates of elements from those pools into organic forms are usually low. The microbially-mediated fixation of atmospheric $\mathrm{N}$ into organic forms by legumes is an obvious and important exception to that generalization.

Most discussions of nutrient cycling in forage systems emphasize the following pools: (i) soil organic matter, which, in more complex analyses, may be considered as multiple pools or fractions; (ii) living plant biomass,

Forages: The Science of Grassland Agriculture, Volume II, Seventh Edition.

Edited by Kenneth J. Moore, Michael Collins, C. Jerry Nelson and Daren D. Redfearn.

(C) 2020 John Wiley \& Sons Ltd. Published 2020 by John Wiley \& Sons Ltd. 
including above- and belowground tissues; (iii) plant residues (dead, relatively undecomposed plant tissues); (iv) living animal biomass, the most obvious being the grazing animal, but the most abundant being above- and belowground invertebrates and microbial populations; and (v) a small but critical pool of plant-available mineral forms of elements necessary for plant growth.

This last pool, the concentration of soil $\mathrm{NO}_{3}{ }^{-}$and $\mathrm{NH}_{4}{ }^{+}$in the case of $\mathrm{N}$, deserves special attention. This pool is often measured as an index of site fertility or nutrient availability but, technically speaking, a pool or concentration is not a measure of nutrient availability, which is a flux or rate. Though the concentration of mineral soil $\mathrm{N}$ in a grassland may be very low on average, this tells us little about the rate at which $\mathrm{N}$ is being made available for plant uptake, which could be high in a fertile soil and low in an infertile soil (Robertson et al. 1999).

Simply put, pools have units of mass $\left(\mathrm{kg} \mathrm{ha}^{-1}, \mathrm{~g} \mathrm{~m}^{-2}\right.$, $\mathrm{mg} \mathrm{kg}^{-1}$, etc.) whereas fluxes have units of mass transferred per unit time $\left(\mathrm{kg} \mathrm{ha}^{-1} \mathrm{yr}^{-1}, \mathrm{~g} \mathrm{~m}^{-2} \mathrm{~d}^{-1}\right.$, etc.). In a systems approach, residence times are the ratios of pools to fluxes and have units of time, because the units of mass cancel. Pools with short residence times are dynamic and are expected to change as management or environmental fluctuations affect the system. For example, consider a hypothetical grassland in which the only source of mineral $\mathrm{N}$ for plant uptake is net $\mathrm{N}$ mineralization, the flux from soil organic $\mathrm{N}$ to soil mineral $\mathrm{N}$, and in which the soil organic matter pool of $\mathrm{N}$ contains $5000 \mathrm{~kg} \mathrm{Nha}^{-1}$, the soil mineral $\mathrm{N}$ pool contains $5 \mathrm{~kg} \mathrm{~N} \mathrm{ha}^{-1}$, and the annual net $\mathrm{N}$ mineralization rate is $50 \mathrm{~kg} \mathrm{ha}^{-1} \mathrm{yr}^{-1}$. In this case, the residence time of $\mathrm{N}$ in soil organic matter would be 100 years, whereas the residence time of mineral soil $\mathrm{N}$ would be 0.1 year or 36.5 days. The turnover rate of a nutrient pool is simply the inverse of the residence time. In this example, the mineral soil $\mathrm{N}$ pool "turns over" 10 times, whereas only $1 \%$ of the soil organic $\mathrm{N}$ pool turns over per year.

Calculations of residence times assume a steady state or equilibrium. Although never completely valid, it is often a useful starting point in analyzing system behavior (Chapin et al. 2011). In a steady state, pool sizes and flux rates are constant, and fluxes into and out of each pool must balance. This includes net fluxes into and out of the total system.

A system dominated by internal recycling of nutrients with relatively small inputs (e.g. fertilizer or $\mathbf{N}$ fixation) and outputs (e.g. leaching or animal and forage offtake) is considered relatively closed. As management intensity increases in forage systems, nutrient cycles inevitably become more open. Because nutrients such as $\mathrm{N}$ and $\mathrm{P}$ behave differently, one element in a system may have a relatively open nutrient cycle, whereas another element's cycle is relatively closed. For example, grasslands receiving animal manures may be managed to minimize $\mathrm{N}$ losses, yet still have significant P losses (Wood et al. 2012).

\section{Why Does Nitrogen Frequently Limit Forage Production?}

Nitrogen is the dominant nutrient constraint on primary production in most forage systems, though a study replicated across several continents suggests that $\mathrm{N}$ and $\mathrm{P}$ collectively constrain productivity in many grasslands (Vitousek 2015). All terrestrial ecosystems have access to a near infinite pool of $\mathrm{N}$ in the atmosphere, which contains $78 \% \mathrm{~N}_{2}$ gas. Many genera of bacteria are able to break the triple bonds of $\mathrm{N}_{2}$ and reduce ("fix") it to $\mathrm{NH}_{4}{ }^{+}$. These bacteria include both symbiotic $\mathrm{N}$ fixers such as Rhizobium (associated with legumes) and Frankia (associated with woody species including Alnus and Ceanothus), and free-living $\mathrm{N}$ fixers such as Azotobacter and Nostoc (Paul 2015). Despite the abundant source of $\mathrm{N}$, and a pathway for its incorporation into the ecologic cycle, most natural and managed ecosystems are $\mathrm{N}$ limited (Houlton et al. 2008).

Hypotheses for widespread $\mathrm{N}$ limitation involve the mass balance of inputs and outputs of $\mathrm{N}$ from terrestrial ecosystems. Until the advent of fossil fuel combustion, atmospheric inputs of $\mathrm{N}$ to ecosystems were generally small to negligible $\left(1-5 \mathrm{~kg} \mathrm{Nha}^{-1} \mathrm{yr}^{-1}\right)$. Sources of $\mathrm{NO}_{3}^{-}$and $\mathrm{NH}_{4}^{+}$deposition included fixation in the atmosphere by lightning, and volatilization from oceanic sources in coastal regions (Galloway et al. 2008). Biologic $\mathrm{N}$ fixation, in contrast, can potentially add $>200 \mathrm{~kg} \mathrm{~N} \mathrm{ha}^{-1} \mathrm{yr}^{-1}$ to ecosystem $\mathrm{N}$ cycles (Figure 11.1).

Biologic $\mathrm{N}$ fixation has three general constraints. First, $\mathrm{N}$ fixation is energetically expensive. Thus, legumes fixing $\mathrm{N}$ divert energy from growth, giving them a disadvantage in competition for light with non- $\mathrm{N}$ fixers. $\mathrm{N}$ fixation is generally restricted to open, high-light environments such as deserts, grasslands, and savannas (Houlton et al. 2008). Leguminous trees in dense forests are rarely nodulated and probably contribute little to forest $\mathrm{N}$ cycles.

Second, biologic $\mathrm{N}$ fixation may frequently be limited by the availability of other elements. The biochemistry of $\mathrm{N}$-fixation requires significant $\mathrm{P}$, iron, sulfur, and molybdenum. In highly weathered and low-pH soils, these elements, though present, may be immobilized in a variety of geochemical forms. Increased grassland productivity in many tropical and subtropical regions may ultimately be limited by non- $\mathrm{N}$ nutrient constraints on legumes, especially P. Moore (1970) concluded that $\mathrm{N}$ is almost universally deficient in humid tropical and subtropical grasslands. However, "for the successful establishment of tropical grass and legume mixtures, every encouragement must be given to the legumes" (Moore 1970). In tropical grasslands, which are often affected by low $\mathrm{P}$ and micronutrient availability, $\mathrm{P}$ and micronutrient fertilizer additions are 



FIG. 11.1. Ranges of reported symbiotic $\mathrm{N}_{2}$ fixation by temperate (left panel) and tropical (right panel) forage legumes (Russelle 2008). Dinitrogen fixation by temperate legumes in mixtures with nonlegumes is shown by the upper line of a pair, whereas $\mathrm{N}_{2}$ fixation in pure stands is shown by the lower line.

critical to the establishment of legumes and subsequent improvements in the $\mathrm{N}$ budget.

The third general constraint on the abundance of $\mathrm{N}$-fixing plants is herbivory. Plant productivity in most temperate terrestrial ecosystems is $\mathrm{N}$-limited, and, as a consequence, the protein concentration of available forage is low. Legumes, which generally have high leaf $\mathrm{N}$ concentrations, are often targeted by both generalist herbivores, such as large ruminants, and specialist herbivores, such as many invertebrates. Reducing herbivory has led to increased legume abundance and greater $\mathrm{N}$ fixation in a variety of ecosystems. In areas with a long evolutionary history of grazing, such as Africa, legumes have often countered the threat of herbivory with physical (e.g. thorns) or chemical (e.g. alkaloid) defenses (see Chapters 46 and 47).

Nitrogen loss from ecosystems may be as important as constraints on $\mathrm{N}$ inputs in explaining the chronic $\mathrm{N}$ limitation found in many temperate, terrestrial ecosystems. Because the $\mathrm{N}$ cycle is prone to both gaseous losses $\left(\mathrm{NH}_{3}\right.$ volatilization, denitrification, combustion losses during fire) and leaching losses $\left(\mathrm{NO}_{3}{ }^{-}\right.$and, to a lesser degree, dissolved organic $\mathrm{N}[\mathrm{DON}])$, it is inherently leakier than the cycles of $\mathrm{P}, \mathrm{K}, \mathrm{Ca}$, and various micronutrients (Chapin et al. 2011). The availability of $P$ or Fe may decrease over time in a particular ecosystem, as those elements are chemically immobilized by reactions with soil and subsoil minerals, but, unless erosion or surface runoff occurs, those elements are rarely exported from the local system. In contrast, $\mathrm{N}$ losses inevitably increase when ecosystems are disturbed (e.g. tillage, grazing, or fire) and plant uptake from the soil mineral $\mathrm{N}\left(\mathrm{NO}_{3}{ }^{-}\right.$and $\left.\mathrm{NH}_{4}{ }^{+}\right)$pool is disrupted (Houlton et al. 2008; Vitousek et al. 2009).

\section{Nitrogen in the Plant-Soil System}

In the long-term (centuries to millennia), net inputs and outputs of $\mathrm{N}$ play a large role in determining a particular ecosystem's fertility. In the short-term, however, the supply rate of plant-available mineral soil $\mathrm{N}$ in an unfertilized ecosystem is regulated by soil biologic activities. A diverse community of soil invertebrates, bacteria, and fungi is responsible for physically and chemically breaking down large organic molecules into smaller organic molecules, $\mathrm{CO}_{2}$, and various mineral nutrients (Robertson and Groffman 2015). The list of new techniques for assessing the functional, taxonomic, and genetic diversity of soil communities is growing rapidly, but will not be discussed here (Fierer and Jackson 2006). 
By far the largest pool of $\mathrm{N}$ (excluding the atmosphere) in grassland and forage systems is soil organic matter. The key flux from that pool is net $\mathrm{N}$ mineralization, defined as the microbially mediated release of $\mathrm{NH}_{4}{ }^{+}$and $\mathrm{NO}_{3}{ }^{-}$ from soil organic matter and plant residues. Various net $\mathrm{N}$ mineralization assays provide key insights into soil fertility and the degree to which $\mathrm{N}$ may limit plant productivity (Robertson et al. 1999). Mineralization together with biologic $\mathrm{N}$ fixation, $\mathrm{N}$ returned by grazing animals, and fertilizer or atmospheric $\mathrm{N}$ inputs, make up an ecosystem's $\mathrm{N}$ supply rate.

Treating net $\mathrm{N}$ mineralization as a single process or flux ignores much of the complexity of soil $\mathrm{N}$ dynamics. In the transition from organic matter to mineral $\mathrm{N}$, organic substrates must first be broken down into soluble compounds, the DON pool. The DON pool is the focus of recent attention for several reasons (Jones et al. 2004; Chapin et al. 2011). First, organic compounds must be broken down to DON before they can be absorbed and mineralized by microbes. Second, leaching losses of DON, although rarely measured, may be a significant component of the $\mathrm{N}$ budget in some ecosystems (Jones et al. 2004). Third, direct uptake of DON by plant roots or associated mycorrhizae has been documented in numerous ecosystems. Most of the reported cases involve uptake of neutrally charged amino acids such as glycine in cold, wet, and/or acidic environments such as tundra and conifer forests, where up to $65 \%$ of plant $\mathrm{N}$ uptake has been attributed to DON (Chapin et al. 2011). Because the direct uptake of DON short-circuits the role of $\mathrm{N}$ mineralization and the importance of $\mathrm{NH}_{4}^{+}$and $\mathrm{NO}_{3}{ }^{-}$availability, researchers are reconceptualizing $\mathrm{N}$ cycling where DON uptake has been documented. Plant DON uptake in temperate grasslands is documented (e.g. Wilkinson et al. 2015), but its role in the $\mathrm{N}$ cycle of managed forage systems is still unsettled.

Microbial decomposers break down DON as an energy source, respiring $\mathrm{CO}_{2}$, and releasing $\mathrm{NH}_{4}{ }^{+}$as a by-product. In aerobic soils, much of this $\mathrm{NH}_{4}^{+}$is subsequently nitrified to $\mathrm{NO}_{3}{ }^{-}$by bacteria that oxidize $\mathrm{NH}_{4}{ }^{+}$as an energy source (Robertson and Groffman 2015). This is the key step in $\mathrm{N}$ mineralization and the total amount of mineral $\mathrm{N}$ released is called gross mineralization. Much of this $\mathrm{NH}_{4}{ }^{+}$and $\mathrm{NO}_{3}{ }^{-}$may be reabsorbed or immobilized by the microbial community, however, in order to meet nutritional needs. If the C: $N$ ratio of decomposing organic matter is high, $\mathrm{N}$ is limiting for microbes relative to labile organic $C$ (their energy source) and little if any net release, or net mineralization, of $\mathrm{NH}_{4}{ }^{+}$into the soil occurs.

A C: $\mathrm{N}$ ratio of $25-35$ is generally accepted as a critical ratio for net $\mathrm{N}$ mineralization from decomposing plant residues. This is somewhat higher than the $\mathrm{C}: \mathrm{N}$ ratio of microbial biomass (generally about 10 ), but also reflects microbial growth efficiency (the proportion of consumed
$\mathrm{C}$ incorporated into growth vs respired) (Robertson and Groffman 2015). At C: $\mathrm{N}$ ratios less than the critical level, the sink for $\mathrm{NO}_{3}{ }^{-}$and $\mathrm{NH}_{4}{ }^{+}$provided by microbial immobilization disappears and net mineralization increases sharply. The presence of this critical ratio or breakpoint in $\mathrm{N}$ cycling (the shift from immobilization to net mineralization) means that soil $\mathrm{N}$ availability and ecosystem $\mathrm{N}$ losses may respond non-linearly to gradual changes in fertilization, herbivory, or other processes in forage systems (Wedin and Tilman 1996).

Because of the strong role of plant tissue chemistry in regulating the $\mathrm{N}$ cycle, it is not valid to consider soil $\mathrm{N}$ availability as an abiotic or soil property in isolation from the characteristics of past and present vegetation (Wedin 1995). The C: $\mathrm{N}$ ratios of plant residues affect both the rate of decomposition and the balance between $\mathrm{N}$ immobilization by microbes and net $\mathrm{N}$ mineralization (Chapin et al. 2011). In addition, the $C$ chemistry of plant tissue strongly affects how it decomposes and contributes to formation of soil organic matter.

Lignin in aboveground tissues and suberin in roots are energetically expensive to break down for microbes and slow to decompose. Much of the polyphenolic ring structure of lignin is not broken-down during decomposition, but is instead transformed and incorporated into large-molecular-weight amorphous compounds known as soil humus. During this transformation, considerable $\mathrm{N}$ is tied up in the transformed $\mathrm{C}$ rings. Thus, though the $\mathrm{C}: \mathrm{N}$ ratio of humus is quite low (10-20), the energetic costs for microbes utilizing humus-bound $\mathrm{N}$ are high and its contribution to net mineralization is often low. As humus binds with clay or is protected in soil aggregates, its availability for decomposition and mineralization decreases further.

A number of decomposition studies suggest that approximately $20 \%$ of decomposing plant residues become stabilized as soil organic matter (Chapin et al. 2011). Using a simple model of $\mathrm{N}$ immobilization and soil organic matter formation, Knops et al. (2002) suggested that no net mineralization occurs in decomposing plant residues if they initially contain less than $0.75 \% \mathrm{~N}$. All of the $\mathrm{N}$ becomes incorporated into soil organic matter. Although $0.75 \% \mathrm{~N}$ is low for aboveground plant tissues in managed cool-season pastures, it is typical for aboveground senesced tissues of unfertilized $\mathrm{C}_{4}$ grasses. It is also a typical $\mathrm{N}$ concentration for roots in unfertilized stands of both cool season and warm season grasses. The low rates of net $\mathrm{N}$ mineralization observed in many grasslands, and their ability to build soil organic matter rich in $\mathrm{N}$ are related, especially considering that roots make up over one-half of net primary production in most grasslands.

The $\mathrm{N}$ in soil organic matter in grasslands generally ranges from 5000 to over $20000 \mathrm{~kg} \mathrm{Nha}^{-1}$. Net $\mathrm{N}$ mineralization rates generally range from 20 to $80 \mathrm{~kg} \mathrm{Nha}^{-1} \mathrm{yr}^{-1}$, so the residence time of $\mathrm{N}$ in soil 
organic matter would be centuries in most grasslands. Thus, soil organic matter does not appear to be a dynamic pool. However, numerous studies have shown that net $\mathrm{N}$ mineralization in grassland soils is dynamic, responding within months to fire, grazing, or changes in plant species composition. This conflict illustrates the point that soil organic matter does not behave as a single pool when considering $\mathrm{N}, \mathrm{C}$, or other elemental cycles.

Numerous methods have been published for partitioning soil organic matter into chemical, physical, or functional fractions or pools. Many grassland studies follow the CENTURY model (Parton et al. 1987), which partitions soil organic matter into three fractions. The "active" fraction contains low-molecular-weight fractions of recently added plant residues and live microbial biomass. It makes up $2-8 \%$ of total soil organic matter and has a residence time of 1-5 years. The "slow" pool makes up $40-60 \%$ of soil organic matter and has a residence time of $20-50$ years. The "passive" pool makes up $30-50 \%$ of soil organic matter and has a residence time of over 1000 years. The slow and passive pools are strongly affected by soil texture and climate. These two pools comprise the vast majority of soil organic matter, yet they contribute less than $30 \%$ of the net $\mathrm{N}$ mineralization from grassland soils (Schimel et al. 1994). Various methods of soil organic matter fractionation all indicate that a small, highly active soil organic matter fraction (e.g. CENTURY's "active" fraction) dominates soil biologic activity, including $\mathrm{N}$ cycling (McLauchlan and Hobbie 2004).

Referring to tropical grasslands and savannas, Huntley and Walker (1982) said " $\mathrm{N}$ has been shown to be of great significance ... but despite many thousands of $\mathrm{N}$ measurements, in all its forms, an understanding of the $\mathrm{N}$ cycle still eludes us." Subsequent $\mathrm{N}$ cycling research in grassland/forage systems has emphasized the strong linkages between vegetation and the small active fraction of soil organic matter. In unfertilized humid and subhumid grasslands, this plant-soil interaction reinforces low soil $\mathrm{N}$ availability (Wedin 1995; Dubeux et al. 2007). The low tissue $\mathrm{N}$ concentrations of senesced grass leaves and roots lead to microbial $\mathrm{N}$ immobilization, reducing net $\mathrm{N}$ mineralization, which, in turn, reduces both forage production and forage quality. Low soil moisture in semiarid and arid grasslands constrains both soil microbes and plants, and the role of plant-soil interactions in regulating $\mathrm{N}$ cycling is less clear (Burke et al. 1998; McCulley et al. 2009). To address the natural tendency toward $\mathrm{N}$ limitation in grasslands, forage production in humid regions has relied on increasing $\mathrm{N}$ inputs ( $\mathrm{N}$ fixation by legumes, animal wastes, inorganic $\mathrm{N}$ fertilizer) and managing the plant-soil-grazer (livestock) system to enhance $\mathrm{N}$ cycling (Dubeux et al. 2007).

\section{Legumes and $\mathbf{N}_{\mathbf{2}}$ Fixation}

Dinitrogen fixation by legumes depends on many factors, including host species and genotype, rhizobial strain and population size, developmental stage of the host, inorganic $\mathrm{N}$ (mainly $\mathrm{NO}_{3}{ }^{-}$) supply, yield of the host, nutrient supply, and toxic element level, and abiotic growing conditions (Russelle 2008; Suter et al. 2015).

There is considerable uncertainty about how much $\mathrm{N}_{2}$ a particular legume will fix. In general terms, $\mathrm{N}_{2}$ fixation by forage legumes usually ranges from 50 to $200 \mathrm{~kg} \mathrm{Nha}^{-1} \mathrm{yr}^{-1}$ (Figure 11.1). Estimates of $\mathrm{N}_{2}$ fixation in white clover-perennial ryegrass mixtures range from 0 to more than $300 \mathrm{~kg} \mathrm{Nha}^{-1} \mathrm{yr}^{-1}$ (Russelle 2008), and $\mathrm{N}_{2}$ fixation in alfalfa-bermudagrass pastures range from 80 to $222 \mathrm{~kg} \mathrm{~N} \mathrm{ha}^{-1} \mathrm{yr}^{-1}$ (Haby et al. 2006). Dinitrogen fixation in pastures tends to be less than in mown forages (Figure 11.1) because of feedback through excreta.

\section{Constraints to $\mathrm{N}_{2}$ Fixation}

Three conditions are necessary for large amounts of symbiotic $\mathrm{N}_{2}$ fixation in mixed forage stands (Soussana and Tallec 2010): (i) high forage yield; (ii) high proportion of legume in the mixture; and (iii) high reliance of the legume on $\mathrm{N}_{2}$ fixation. Legume production may vary from one year to the next, in part because of oscillations in soil $\mathrm{N}$ availability (Loiseau et al. 2001). Maintenance of sufficient legume populations has been difficult in many pastures, due to selective grazing, inadequate soil fertility, stand declines due to pest pressures, and the availability of inexpensive $\mathrm{N}$ fertilizers. However, as the economic and environmental costs of producing $\mathrm{N}$ fertilizer increase, interest in using mixed stands of legumes and grass is once again increasing (Wood et al. 2012; Lüscher et al. 2014).

\section{Pathways of N Transfer}

The transfer of $\mathrm{N}$ from legumes to non-legumes is due to: (i) exudation and leakage of $\mathrm{N}$ from roots and nodules; (ii) senescence and degradation of nodules or roots; (iii) direct transfer from legume roots to nonlegume roots through connections made by arbuscular mycorrhizal fungal hyphae; (iv) $\mathrm{NH}_{3}$ loss from legume herbage and reabsorption by grass herbage; (v) movement of $\mathrm{N}$ from legume herbage to the soil by leaching or decomposition of surface litter; and (vi) redeposition of consumed N by livestock (Russelle 2008). Oscillations in legume population also contribute to $\mathrm{N}$ transfer to nonlegumes.

Of these, the two most important appear to be decomposition of plant residues, both below and above ground, and the return of $\mathrm{N}$ through deposition of livestock excreta. Ledgard (1991), for instance, found $\mathrm{N}$ transfer below ground from white clover to perennial ryegrass in a pasture (70 $\mathrm{kg} \mathrm{N} \mathrm{ha}^{-1} \mathrm{yr}^{-1}$ ) was similar to that transferred through excreta $\left(60 \mathrm{~kg} \mathrm{Nha}^{-1} \mathrm{yr}^{-1}\right)$. Nearly half of the annual $\mathrm{N}_{2}$ fixed by clover $\left(270 \mathrm{~kg} \mathrm{~N} \mathrm{ha}^{-1} \mathrm{yr}^{-1}\right)$ was transferred to the grass under these conditions. 
What proportion of a mixed stand must be comprised of legumes to provide sufficient $\mathrm{N}$ to the nonlegume? In grazed white clover/perennial ryegrass, (Sheehy 1989) estimated $41 \mathrm{~kg} \mathrm{Nha}^{-1} \mathrm{yr}^{-1}$ was needed to sustain the system, and this may be achieved with clover contents of about $10 \%$ on an area basis. In Brazil, calopo should make up $13-23 \%$ of the forage dry mass for the sustainability of a mixture with Brachiaria (Cadisch et al. 1994). The required proportion of legume in a stand varies with how the forage is used, which depends on livestock species, stocking rate, management, and forage palatability (Lüscher et al. 2014).

Palatable legumes are grazed selectively and need to comprise $20-30 \%$ of the pasture herbage dry matter when pasture utilization (consumption by livestock) is between $10 \%$ and $40 \%$. However, with higher utilization rates (40-70\%), legumes must comprise up to $45 \%$ of total dry matter (Thomas 1992). Decreasing the palatability of legumes by planting species or genotypes with higher tannin concentrations, for example, may provide a partial solution to the problem of maintaining legume populations at desirable levels. Factors affecting palatability are discussed in Chapters 46 and 47.

\section{Transfer of Fixed $\mathrm{N}$ in Mixtures}

It is unclear how much fixed $\mathrm{N}$ is transferred from legumes to nonlegumes growing in mixtures because a wide range of estimates has been reported. This is likely due to the large number of interacting conditions that affect $\mathrm{N}_{2}$ fixation. Transfer of fixed $\mathrm{N}$ is positively related to the proportion of legume $\mathrm{N}$ derived from the atmosphere; therefore, more fixed $\mathrm{N}$ is transferred under low- $\mathrm{N}$ fertility conditions. More $\mathrm{N}$ transfer occurs with a higher proportion of legumes in the stand (Russelle 2008). This is due both to greater competition for soil $\mathrm{N}$ by the nonlegume and a larger "pool" of fixed $\mathrm{N}$ being added to the system.

Transfer of $\mathrm{N}$ increases with stand age in perennial forage mixtures, presumably because of increased reliance of the legume on $\mathrm{N}_{2}$ fixation and cumulative decomposition of above and belowground tissue (Jorgensen et al. 1999). Maximum $\mathrm{N}$ transfer from alfalfa to meadow bromegrass was $55 \mathrm{~kg} \mathrm{Nha}^{-1} \mathrm{yr}^{-1}$ (Walley et al. 1996) and from white clover to perennial ryegrass was $43 \mathrm{~kg} \mathrm{Nha}^{-1} \mathrm{yr}^{-1}$ (McNeill and Wood 1990), though a lower value $\left(18 \mathrm{~kg} \mathrm{Nha}^{-1} \mathrm{yr}^{-1}\right)$ was reported for an alfalfa-bermudagrass mixture (Haby et al. 2006).

\section{Nitrogen in the Plant-Soil-Grazer System}

Cattle, sheep, and other large herbivores affect plant growth rates, plant species abundance, and plant elemental composition by removing herbage, trampling vegetation, compacting soil, and excreting waste. All these effects alter the rate of $\mathrm{N}$ transformations, the fate of $\mathrm{N}$, and, ultimately, the $\mathrm{N}$ balance of pastures.
Growing ruminants utilize $5-10 \%$ of the feed $\mathrm{N}$ they consume, and lactating dairy cows utilize 15-30\% for milk production (Haynes and Williams 1993); the remainder is excreted. Fecal $\mathrm{N}$ is mostly insoluble in water and comprises microbial cells (50-65\%), undigested plant residues (15-25\%), and products of livestock metabolism (Haynes and Williams 1993). Urinary N is largely soluble and in the form of urea (60-90\%) and other metabolic products, such as hippuric acid, creatine/creatinine, and allantoin. Consequently, fecal $\mathrm{N}$ contributes mainly to medium- to long-term $\mathrm{N}$ cycling processes, whereas urinary $\mathrm{N}$ is subject to rapid cycling and loss.

Nitrogen use efficiency (NUE) by the animal is low, and more $\mathrm{N}$ is excreted in urine when the diet is rich in degradable protein and low in available energy. Conversely, proper supplementation of pastures with digestible energy improves NUE and reduces $\mathrm{N}$ excretion. On the other hand, diet composition causes little change in fecal $\mathrm{N}$ output. Urinary $\mathrm{N}$ output by sheep was lower on perennial ryegrass/white clover swards $\left(54 \mathrm{~g} \mathrm{~N} \mathrm{~d}^{-1}\right)$ than on perennial ryegrass fertilized with $420 \mathrm{~kg} \mathrm{Nha}^{-1} \mathrm{yr}^{-1}\left(82 \mathrm{~g} \mathrm{~N} \mathrm{~d}^{-1}\right)$, but there was no change in fecal $\mathrm{N}$ output (Parsons et al. 1991).

\section{Patchiness of Nitrogen Distribution in Pastures}

Concentrated excreta patches generally affect from 14\% to $30 \%$ of the land area of a pasture annually, assuming the patches do not overlap (Whitehead 2000; Moir et al. 2011). Soil sampling must be more intensive than in mechanically harvested forages to produce accurate maps of nutrient distribution. Optimum fertilization of grazed pastures with $\mathrm{N}$ requires site-specific application, but most farmers in North America have not adopted this practice with forages. More research is needed on this topic, because benefits of site-specific $\mathrm{N}$ applications in pastures have not been consistent (Cuttle et al. 2001).

More excreta are "deposited" in areas where livestock spend time, such as shelter from sun and wind, near field gates, or near watering tanks (Bogaert et al. 2000; Augustine et al. 2013). Moving the water supply, or using moveable shade structures, improves nutrient distribution in the pasture, as does short-term, high-stocking rate grazing systems (Peterson and Gerrish 1996).

\section{Nitrogen Losses in Pastures}

In urine spots, the combination of high soil $\mathrm{pH}$ from urea hydrolysis, high $\mathrm{NH}_{4}^{+}$concentration, and high osmotic strength increases $\mathrm{NH}_{3}$ volatilization and slows nitrification. Gaseous $\mathrm{NH}_{3}$ losses increase with soil temperature and lower soil moisture, making it the primary pathway of $\mathrm{N}$ loss in grazed semiarid grasslands. Under subhumid and humid pasture conditions, $\mathrm{NH}_{3}$ losses account for between 2 and 25\% of urinary N (Mulvaney et al. 2008). Higher $\mathrm{NH}_{3}$ loss rates from urine and manure occur for concentrated or confined animals (Powell and 
Rotz 2015). Gaseous N loss by denitrification can be significant when soils become waterlogged and anoxic (Robertson and Groffman 2015), but generally accounts for only a few percent of urinary-N loss (Luo et al. 1999).

Nitrate leaching loss may be larger under grazing than mechanical harvesting, but this depends on the amount and timing of excess soil water, soil texture, the general level of $\mathrm{N}$ fertility, and crop growth. The amount of available $\mathrm{N}$ in a urine spot (up to $250 \mathrm{~kg} \mathrm{~N} \mathrm{ha}^{-1}$ for sheep and $1000 \mathrm{~kg} \mathrm{~N} \mathrm{ha}^{-1}$ for dairy cattle; Steele 1987) greatly exceeds the $\mathrm{N}$ needs of neighboring plants. High $\mathrm{NO}_{3}{ }^{-}$ leaching losses occur when precipitation or irrigation occurs during periods of high $\mathrm{NO}_{3}{ }^{-}$concentrations (Wood et al. 2012).

Intensive grassland management in humid climates has been implicated in $\mathrm{NO}_{3}{ }^{-}$contamination of ground water and surface water (Galloway et al. 2008; NRC 2009; Vitousek et al. 2009). Because $\mathrm{N}$ is redeposited by livestock, the probability of $\mathrm{NO}_{3}{ }^{-}$leaching losses is higher with higher $\mathrm{N}$ fertilizer or manure rates under grazing than under mowing. In New Zealand, for example, critical $\mathrm{N}$ application rates were $200-300 \mathrm{~kg} \mathrm{~N} \mathrm{ha}^{-1} \mathrm{yr}^{-1}$ lower for grazed than mown forages to maintain leachate $\mathrm{NO}_{3}{ }^{-}$concentrations below the drinking water standard (Di and Cameron 2000). Leaching losses may also be large for pastures on shallow soils in the humid eastern US, especially with high addition rates of $\mathrm{N}$ fertilizer, manure, or biosolids (Stout et al. 2000). This problem has increased in the southeastern US in recent decades with the growth of the poultry industry (Wood et al. 2012). In the Midwest, however, where deeper soils and lower rainfall are typical, $\mathrm{NO}_{3}{ }^{-}$leaching losses from forage systems are small if $\mathrm{N}$ addition rates are low to moderate (Russelle 1996; Powell and Rotz 2015).

Excellent management of legume/grass mixtures can yield moderate to high animal production levels with modest N losses (Russelle 2008). As indicated above, it is often difficult to maintain sufficient legume populations in mixed stands under grazing. The solution to this site-specific problem requires integrated knowledge of plant characteristics, soil conditions, weather, livestock management, pest pressure, and fertilizer and lime management.

\section{Phosphorus Cycling in Forage System}

After N, P is the nutrient receiving most attention in forage systems. Though plant tissue concentrations of $\mathrm{P}$ are much lower than $\mathrm{N}, \mathrm{P}$ can nevertheless limit plant productivity under some circumstances. Like $\mathrm{N}$, concern over runoff and leaching of $\mathrm{P}$ from agricultural landscapes has also increased dramatically in recent decades (Wood et al. 2012). However, the P cycle has important differences from the $\mathrm{N}$ cycle that must be considered whether the goal is optimizing $\mathrm{P}$ supply for plant and animal production, minimizing $\mathrm{P}$ losses to the environment, or, as is increasingly the case, both.

The various transformations that regulate soil $\mathrm{N}$ availability (i.e. $\mathrm{N}$ mineralization) are almost entirely microbially driven (Robertson and Groffman 2015). Abiotic soil factors, such as low $\mathrm{pH}$, impact $\mathrm{N}$ availability through their effects on microbes and plants. In contrast, phosphate ions $\left(\mathrm{PO}_{4}{ }^{3-}\right.$, the main form of available $\mathrm{P}$ in soils) easily form chemical bonds with various minerals (Smil 2000). The resulting precipitates are generally unavailable to plants and are known as occluded P. The chemical reactions that $\mathrm{PO}_{4}{ }^{3-}$ undergoes depend on the concentrations of other minerals and $\mathrm{pH}$. At low $\mathrm{pH}$, $\mathrm{PO}_{4}{ }^{3-}$ binds with oxides of $\mathrm{Fe}, \mathrm{Al}$, and $\mathrm{Mn}$ to form insoluble precipitates. As rock weathers (a process that occurs over millennia), the abundance of $\mathrm{Fe}, \mathrm{Al}$, and $\mathrm{Mn}$ oxides increases. Thus, highly weathered, ancient soils such as those found throughout the tropics, have a high potential to chemically immobilize available $\mathrm{P}$ (Chapin et al. 2011). At high $\mathrm{pH}, \mathrm{PO}_{4}{ }^{3-}$ binds with $\mathrm{Ca}$ to form various calcium phosphates that also precipitate and are relatively unavailable for plant uptake. Thus, $\mathrm{P}$ availability is highest at soil $\mathrm{pH}$ values around 6.5 and is less available at both higher and lower values.

The rapid geochemical immobilization of $\mathrm{PO}_{4}{ }^{3-}$ in most soils also explains why leaching of $\mathrm{PO}_{4}{ }^{3-}$ into groundwater is rare (Smil 2000). When P inputs to the soil are high, for instance, with repeated additions of animal wastes to forage systems, the geochemical potential of upper soil horizons to immobilize or precipitate $\mathrm{P}$ may be reduced. Soil solution concentrations of $\mathrm{PO}_{4}{ }^{3-}$ may increase near the surface under these circumstances. In regions of high precipitation, $\mathrm{PO}_{4}{ }^{3-}$ and $\mathrm{P}$ associated with dissolved organic matter may leach into lower soil horizons, but $\mathrm{P}$ is usually immobilized at that point. This contrasts sharply with $\mathrm{NO}_{3}{ }^{-}$, which readily moves with percolating water to great depths and frequently enters groundwater. Like $\mathrm{N}$, high concentrations of soluble and particulate $\mathrm{P}$ near the soil surface are vulnerable to loss through runoff and associated soil erosion (Wood et al. 2012).

In contrast to $\mathrm{N}_{2}$ gas for $\mathrm{N}$, there is no atmospheric or gaseous pool of $\mathrm{P}$ to replenish terrestrial and aquatic ecosystems. Rather, the ultimate source of $\mathrm{P}$ cycling in natural ecosystems is rock weathering, a process that is very slow compared with $\mathrm{N}_{2}$ fixation by legumes and other N-fixing organisms (Chapin et al. 2011). P is abundant in many of the minerals, such as apatite, that form rock, but the solubility of these minerals is low. Because $\mathrm{P}$ has no atmospheric pool and the solubility and transport of $\mathrm{PO}_{4}{ }^{3-}$ in soil solutions is low, the linkages between terrestrial $\mathrm{P}$ and aquatic $\mathrm{P}$ cycles are weak. Simply put, natural terrestrial ecosystems do not leak $\mathrm{P}$ to nearby freshwater ecosystems the way they leak $\mathrm{N}$. In addition, in aquatic ecosystems $\mathrm{P}$ is limited by the 
lack of a biotic mechanism for $\mathrm{P}$ inputs equivalent to $\mathrm{N}$-fixing cyanobacteria in the plankton. Thus, freshwater ecosystems are often highly responsive and vulnerable to human-caused P loading (Chapin et al. 2011).

Because of concerns over eutrophication of aquatic systems (NRC 2009), P management is becoming increasingly important in forage and livestock management (Rotz et al. 2002; Jarvie et al. 2015). With the development of Total Maximum Daily Loads (TMDLs) for P pollution in surface-water bodies, the Natural Resources Conservation Service (NRCS) and state agencies have begun to institute limitations on $\mathrm{P}$ application to agricultural and residential land (reviewed by Wood et al. 2012). In particular, long-term additions of animal manures or biosolids to pasture and hayland near concentrated animal feeding operations have created chronic P pollution problems. Because animal manures, particularly poultry, have relatively high $\mathrm{P}$ concentrations, manure application rates calculated to meet plant $\mathrm{N}$ needs of forage systems result in the application of 2-4 times greater $\mathrm{P}$ than plants are able to use (Wood et al. 2012). Some states limit P addition to fields based on high soil test P levels, whereas others use a P risk index that assesses the likelihood of P loss from a field. A P risk index typically includes many factors known to affect runoff, including slope, soil cover, and distance to surface water (Butler et al. 2010). Regardless of the approach, producers who manage manure are being affected by concerns about P losses.

Behind concerns about $\mathrm{P}$ runoff, are the widespread increases in soil test $\mathrm{P}$ levels that have been observed (Wood et al. 2012; Jarvie et al. 2015). Such buildup can be attributed to repeated applications of livestock and poultry waste, overapplication of fertilizer $P$, and large amounts of imported $\mathrm{P}$ in livestock rations that end up in waste. Because of the relatively high $\mathrm{P}$ content of some animal wastes (e.g. poultry litter), soil test P levels will continue to increase even when manure application rates are matched to crop $\mathrm{N}$ requirements (Wood et al. 2012). Where soil test $\mathrm{P}$ levels are high, it may take many years to "crop down" fields high in P by harvesting forages. The $P$ removal in animal products is only $10-35 \%$ of that for harvested forages. Thus, hay sales will send more $\mathrm{P}$ off farm than meat or milk. The best long-term solution to $\mathrm{P}$ accumulation is to reduce the net import of $\mathrm{P}$ to the farm. This can generally be achieved only by reducing input of off-farm P sources (feed, fertilizer, manure, etc.) and increasing export of $\mathrm{P}$ in animal and plant products (Rotz et al. 2002).

Though well-managed perennial pastures provide better soil protection than most annual cropping systems, $\mathrm{P}$ losses from damaged vegetation, thatch, and dung are environmentally important. Loss rates for $\mathrm{P}$ of several $\mathrm{kg} \mathrm{ha}^{-1} \mathrm{yr}^{-1}$ have been measured in snowmelt runoff from hay fields and pastures in cold regions. Surface applications of manure, either as non-incorporated broadcast manure from storage or as dung from grazing stock, are a rich reservoir of water-soluble or biologically available P. As with N, P distribution on a farm is generally heterogeneous because of long-term management decisions (e.g. fields nearest the manure source receive the most manure) and animal behavior (more dung is deposited in areas where livestock rest than in other areas). Decision support tools, such as soil test P levels or P risk indices, need to be used at both the field and the landscape scale to make appropriate decisions about where and when to apply nutrient-rich animal waste (Wood et al. 2012).

\section{The Challenge of "Balancing" Nutrient Budgets}

Lanyon (1995) published a provocative paper entitled "Does nitrogen cycle?: Changes in the spatial dynamics of nitrogen with industrial nitrogen fixation." The simple nutrient cycle diagram found in many ecology or agronomy texts (e.g. $\mathrm{N}$ flowing from soil to plant to animal and back to soil within an idealized field) rarely exists in modern agricultural landscapes. Many, if not most, forage systems have relatively small losses of $\mathrm{N}$ to the atmosphere, groundwater or surface water when compared to arable land at the field level. In contrast, P losses from intensively managed forage systems may approach or exceed values for arable land (NRC 2009). Forage systems are an integral component of modern agriculture, which has dramatically changed local, regional, and global nutrient cycles over the last century (Vitousek et al. 2009). Nutrient outputs (forage, grain, livestock, milk) from one field become intentional or unintentional nutrient inputs to landscapes dozens or hundreds of kilometers away.

This spatial uncoupling of nutrient cycles is combined with unprecedented increases in the magnitude of global nutrient cycles. Human activities (industrial $\mathrm{N}$ fertilizer production, inadvertent $\mathrm{N}$ fixation during fossil fuel combustion, and agricultural management of legumes) have more than doubled the pre-industrial global rate at which atmospheric $\mathrm{N}_{2}$ was transferred (i.e. fixed) to biologically active pools (Galloway et al. 2008). Though the sources of $\mathrm{P}$ inputs differ (e.g. mining), changes in the global $\mathrm{P}$ cycle are of similar magnitude (Smil 2000).

The potential risk of environmental damage from farming systems may be estimated from nutrient budgets. Assuming conservation of mass, the difference between inputs and outputs indicates the mass that is unaccounted for (Chapin et al. 2011). If one assumes steady-state conditions, mass that is not accounted for is presumed to be a net nutrient loss from the system. The simplest approach at the whole-farm level is to measure the difference between purchased inputs and marketed outputs of a given nutrient and to assume steady-state conditions, (e.g. no change in the size of nutrient pools in the soil).

This approach, however, is unlikely to be valid for most situations because management systems (tillage, residue 
removal, crop rotations, fertilizer management, etc.) vary and interact at timescales shorter than those required for equilibrium of the soil pools. In addition, there can be transfers within the farm, such as occur with sediment runoff and deposition that disrupt equilibrium within the farm. The simple balance approach also fails to partition net nutrient losses into specific fluxes, which is critical in determining the broader environmental impacts of local management decisions. For example, while both $\mathrm{NH}_{3}$ volatilization and $\mathrm{N}_{2} \mathrm{O}$ emissions are $\mathrm{N}$ losses to the atmosphere, the former has a short residence time in the atmosphere and relatively local negative impacts, whereas the latter is long-lived in the atmosphere and is a potent greenhouse gas (Robertson and Groffman 2015).

Given the large spatial and temporal heterogeneity in nutrient fluxes, many have used simulation models to estimate flows. For example, Rotz et al. (2002) projected that long-term whole-farm $\mathrm{P}$ balance could be achieved for northeastern US dairy farms by feeding the minimum dietary $\mathrm{P}$ and by maximizing the production and use of forages. Reducing animal $\mathrm{N}$ intake or supplementing a grazing herd with metabolizable energy also reduces environmental risk (Powell and Rotz 2015). Models have been used to estimate watershed or regional results (e.g. Rotz et al. 2005) and these can lead to crucial insights. For example, Nord and Lanyon (2003) found that changing the production strategy (e.g. heavy reliance on purchased feeds) on one farm can have larger effects on watershed nutrient balances than changing farm operations (e.g. field-specific manure application rates) on a number of farms.

As more parameters are used in a model (i.e. symbiotic $\mathrm{N}_{2}$ fixation, net $\mathrm{N}$ mineralization, $\mathrm{NO}_{3}{ }^{-}$leaching, or gaseous losses), more can be inferred about likely nutrient transfers and other pathways of loss, but the number of estimated and uncertain parameters also increases. The nature and magnitude of these uncertainties are important, especially when nutrient budgets are used as policy instruments (Oenema et al. 2003). As farm-scale budgets are aggregated, it is possible to derive general conclusions relevant to watershed and regional spatial scales.

It is difficult to measure nonpoint nutrient losses at large scales, though some pathways are more amenable than others to measurement. P loss (Butler et al. 2010), $\mathrm{N}_{2} \mathrm{O}$ emission (Uchida et al. 2008), $\mathrm{NH}_{3}$ volatilization (Marshall et al. 1998), and $\mathrm{NO}_{3}{ }^{-}$loss through tile drains (Watson et al. 2000) can be measured on field scales. Nutrient losses to streams or groundwater are measurable at the watershed scale (Loecke et al. 2017). Many of these approaches, however, are expensive, difficult to replicate, or restricted to a limited suite of sites. Nevertheless, significant advances in the remote sensing of land cover and land use, the computational power of geographic information systems, and the instrumentation available for environmental monitoring offer potential. Perhaps most of all, the conceptual integration of traditionally separate disciplines such as soil science, hydrology, agronomy, atmospheric science, and ecology provide hope that our ability to understand, predict, and manage nutrient cycles will continue to progress rapidly.

\section{References}

Augustine, D.J., Milchunas, D.B., and Derner, J.D. (2013). Spatial redistribution of nitrogen by cattle in semiarid rangeland. Rangeland Ecol. Manage. 66: 56-62.

Bogaert, N., Salomez, J., Vermoesen, A. et al. (2000). Within-field variability of mineral nitrogen in grassland. Biol. Fertil. Soils 32: 186-193.

Burke, I.C., Lauenroth, W.K., Vinton, M.A. et al. (1998). Plant-soil interactions in temperate grasslands. Biogeochemistry 42: 121-143.

Butler, D.M., Franklin, D.H., Cabrera, M.L. et al. (2010). Assessment of the Georgia phosphorus index on farm at the field scale for grassland management. $J$. Soil Water Conserv. 65: 200-210.

Cadisch, G., Schunke, R.M., and Giller, K.E. (1994). Nitrogen cycling in a pure grass pasture and a grass-legume mixture on a red Latosol in Brazil. Trop. Grasslands 28: 43-52.

Chapin, F.S. III, Matson, P.A., and Vitousek, P.M. (2011). Principles of Terrestrial Ecosystem Ecology, 2e. New York: Springer.

Conant, R.T., Cerri, C.E., Osborne, B.B., and Paustian, K. (2017). Grassland management impacts on soil carbon stocks: a new synthesis. Ecol. Appl. 11: 343-355.

Cuttle, S.P., Scurlock, R.V., and Davies, B.M.S. (2001). Comparison of fertilizer strategies for reducing nitrate leaching from grazed grassland, with particular reference to the contribution from urine patches. J. Agric. Sci. (Cambridge) 136: 221-230.

Di, H.J. and Cameron, K.C. (2000). Calculating nitrogen leaching losses and critical nitrogen application rates in dairy pasture systems using a semi-empirical model. N.Z. J. Agric. Res. 43: 139-147.

Dubeux, J.C.B., Sollenberger, L.E., Mathews, B.W. et al. (2007). Nutrient cycling in warm-climate grasslands. Crop Sci. 47: 915-928.

Fierer, N. and Jackson, R.B. (2006). The diversity and biogeography of soil bacterial communities. Proc. Natl. Acad. Sci. U.S.A. 103: 626-631.

Galloway, J.N., Townsend, A.R., Erisman, J.W. et al. (2008). Transformations of the nitrogen cycle: recent trends, questions, and potential solutions. Science 320: 889-892.

Haby, V.A., Stout, S.A., Hons, F.M., and Leonard, A.T. (2006). Nitrogen fixation and transfer in a mixed stand of alfalfa and bermudagrass. Agron. J. 98: 890-898. 
Haynes, R.J. and Williams, P.H. (1993). Nutrient cycling and soil fertility in the grazed pasture ecosystem. Adv. Agron. 49: 119-199.

Houlton, B.Z., Wang, Y.-P., Vitousek, P.M., and Field, C.B. (2008). A unifying framework for dinitrogen fixation in the terrestrial biosphere. Nature 454: 327-330.

Howarth, R.W., Billen, G., Swaney, D. et al. (1996). Regional nitrogen budgets and riverine $\mathrm{N}$ and $\mathrm{P}$ fluxes for the drainages to the North Atlantic Ocean: natural and human influences. Biogeochemistry 35: 75-139.

Huntley, B.J. and Walker, B.H. (eds.) (1982). Ecology of Tropical Savannas. Ecological Studies no. 42. Berlin: Springer-Verlag.

Jarvie, H.P., Sharpley, A.N., Flaten, D. et al. (2015). The pivotal role of phosphorus in a resilient water-energy-food security nexus. J. Environ. Qual. 44: 1049-1062.

Jones, D.L., Shannon, D., Murphy, D.V., and Farrar, J. (2004). Role of dissolved organic nitrogen (DON) in soil N cycling in grasslands soils. Soil Biol. Biochem. 36: 749-756.

Jorgensen, F.V., Jensen, E.S., and Schjoerring, J.K. (1999). Dinitrogen fixation in white clover grown in pure stand and mixture with ryegrass estimated by the immobilized N-15 isotope dilution method. Plant Soil 208: 293-305.

Knops, J.M.H., Bradley, K.L., and Wedin, D.A. (2002). Mechanisms of plant species impacts on ecosystem nitrogen cycling. Ecol. Lett. 5: 454-466.

Lanyon, L.E. (1995). Does nitrogen cycle?: Changes in the spatial dynamics of nitrogen with industrial nitrogen fixation. J. Prod. Agric. 8: 70-78.

Ledgard, S.F. (1991). Transfer of fixed nitrogen from white clover to associated grasses in swards grazed by dairy cows, estimated using ${ }^{15} \mathrm{~N}$ methods. Plant Soil 131: 215-223.

Loecke, T.D., Burgin, A.J., Riveros-Iregui, D.A. et al. (2017). Weather whiplash in agricultural regions drives deterioration of water quality. Biogeochemistry 133: 7-15.

Loiseau, P., Soussana, J.F., Louault, F., and Delpy, R. (2001). Soil N contributes to the oscillations of the white clover content in mixed swards of perennial ryegrass under conditions that simulate grazing over five years. Grass Forage Sci. 56: 205-217.

Luo, J., Tillman, R.W., and Ball, P.R. (1999). Grazing effects on denitrification in a soil under pasture during two contrasting seasons. Soil Biol. Biochem. 31: 903-912.

Lüscher, A., Mueller-Harvey, I., Soussana, J.F. et al. (2014). Potential of legume-based grassland-livestock systems in Europe: a review. Grass Forage Sci. 69: 206-228.
Marshall, S.B., Wood, C.W., Braun, L.C. et al. (1998). Ammonia volatilization from tall fescue pastures fertilized with poultry litter. J. Environ. Qual. 27: 1125-1129.

McCulley, R.L., Burke, I.C., and Lauenroth, W.K. (2009). Conservation of nitrogen increases with precipitation across a major grassland gradient in the Central Great Plains of North America. Oecologia 159: 571-581.

McLauchlan, K.K. and Hobbie, S.E. (2004). Comparison of labile soil organic matter fractionation techniques. Soil Sci. Soc. Am. J. 68: 1616-1625.

McNeill, A.M. and Wood, M. (1990). ${ }^{15} \mathrm{~N}$ estimates of nitrogen fixation by white clover (Trifolium repens $\mathrm{L}$.) growing in a mixture with ryegrass (Lolium perenne L.). Plant Soil 128: 265-273.

Moir, J.L., Cameron, K.C., Di, H.J., and Fertsak, U. (2011). The spatial coverage of dairy cattle urine patches in an intensively grazed pasture system. J. Agric. Sci. 149: 473-485.

Moore, R.M. (1970). Australian Grasslands. Canberra: Australian National University Press.

Mulvaney, M.J., Cummins, K.A., Wood, C.W. et al. (2008). Ammonia emissions from field-simulated cattle defecation and urination. J. Environ. Qual. 37: 2022-2027.

Nord, E.A. and Lanyon, L.E. (2003). Managing material transfer and nutrient flow in an agricultural watershed. J. Environ. Qual. 32: 562-570.

NRC (2009). Nutrient Control Actions for Improving Water Quality in the Mississippi River Basin and the Northern Gulf of Mexico. Washington, DC: National Academies Press.

Oenema, O., Kros, H., and de Vries, W. (2003). Approaches and uncertainties in nutrient budgets: implications for nutrient management and environmental policies. Eur. J. Agron. 20: 3-16.

Parsons, A.J., Orr, R.J., Penning, P.D., and Lockyer, D.R. (1991). Uptake, cycling and fate of nitrogen in grass-clover swards continuously grazed by sheep. $J$. Agric. Sci. (Cambridge) 116: 47-61.

Parton, W.J., Schimel, D.S., Cole, C.V., and Ojima, D.S. (1987). Analysis of factors controlling soil organic matter levels in Great Plains grasslands. Soil Sci. Soc. Am. J. 51: 1173-1179.

Paul, E.A. (2015). Soil Microbiology, Ecology and Biochemistry, 4e. Burlington, MA: Academic Press.

Peterson, P.R. and Gerrish, J.R. (1996). Grazing systems and spatial distribution of nutrients in pastures: livestock management considerations. In: Nutrient Cycling in Forage Systems Symposium, 7-8 March 1996. Columbia, MO, vol. 1 (eds. R.E. Joost and C.A. Roberts), 203-212. Manhattan, KS: Potash and Phosphate Institute and Foundation for Agronomic Research. 
Powell, J.M. and Rotz, C.A. (2015). Measures of nitrogen use efficiency and nitrogen loss from dairy production systems. J. Environ. Qual. 44: 336-344.

Robertson, G.P. and Groffman, P.M. (2015). Nitrogen transformations. In: Soil Microbiology, Ecology and Biochemistry, 4e (ed. E.A. Paul), 421-446. Burlington, MA: Academic Press.

Robertson, G.P., Wedin, D., Groffman, P.M. et al. (1999). Soil carbon and nitrogen availability: nitrogen mineralization, nitrification, and soil respiration potentials. In: Standard Soil Methods for Long-Term Ecological Research (eds. G.P. Robertson, D.C. Coleman, C.S. Bledsoe and P. Sollins), 258-271. New York: Oxford University Press.

Rotz, C.A., Sharpley, A.N., Satter, L.D. et al. (2002). Production and feeding strategies for phosphorus management on dairy farms. J. Dairy Sci. 85: 3142-3153.

Rotz, C.A., Taube, F., Russelle, M.P. et al. (2005). Whole-farm perspectives on nutrient flows in grassland agriculture. Crop Sci. 45: 2139-2159.

Russelle, M.P. (1996). Nitrogen cycling in pasture systems. In: Nutrient Cycling in Forage Systems Symposium, 7-8 March 1996. Columbia, MO, vol. 1 (eds. R.E. Joost and C.A. Roberts), 125-166. Manhattan, KS: Potash and Phosphate Institute and Foundation for Agronomic Research.

Russelle, M.P. (2008). Biological dinitrogen fixation in agriculture. In: Nitrogen in Agricultural Soils, 2e (eds. J.S. Schepers and W.R. Raun), 281-359. Madison, WI: ASA, CSSA, SSSA.

Schimel, D.S., Braswell, B.H., Holland, E.A. et al. (1994). Climatic, edaphic, and biotic controls over storage and turnover of carbon in soils. Global Biogeochem. Cycles 8: 279-293.

Sheehy, J.E. (1989). How much dinitrogen fixation is required in grazed grassland? Ann. Bot. (London) 64: 159-161.

Simpson, R.J., Stefanski, A., Marshall, D.J. et al. (2015). Management of soil phosphorus fertility determines the phosphorus budget of a temperate grazing system and is the key to improving phosphorus efficiency. Agric. Ecosyst. Environ. 212: 263-277.

Smil, V. (2000). Phosphorus in the environment: natural flows and human interferences. Annu. Rev. Energy Env. 25: $53-88$.

Soussana, J.F. and Tallec, T. (2010). Can we understand and predict the regulation of biological $\mathrm{N}_{2}$ fixation in grassland ecosystems? Nutr. Cycling Agroecosyst. 88: 197-213.

Steele, K.W. (1987). Nitrogen losses from managed grassland. In: Managed Grasslands: Analytical Studies (ed. R.W. Snaydon), 197-204. Amsterdam: Elsevier.
Stout, W.L., Fales, S.L., Muller, L.D. et al. (2000). Water quality implications of nitrate leaching from intensively grazed pasture swards in the northeast US. Agric. Ecosyst. Environ. 77: 203-210.

Suter, M., Connolly, J., Finn, J.A. et al. (2015). Nitrogen yield advantage from grass-legume mixtures is robust over a wide range of legume proportions and environmental conditions. Global Change Biol. 21: 2424-2438.

Thomas, R.J. (1992). The role of the legume in the nitrogen cycle of productive and sustainable pastures. Grass Forage Sci. 47: 133-142.

Uchida, Y., Clough, T.J., Kelliher, F.M., and Sherlock, R.R. (2008). Effects of aggregate size, soil compaction, and bovine urine on $\mathrm{N}_{2} \mathrm{O}$ emissions from a pasture soil. Soil Biol. Biochem. 40: 924-931.

Vitousek, P.M. (2015). Complexity of nutrient constraints. Nat. Plants 1: 1-2.

Vitousek, P.M., Naylor, R., Crews, T. et al. (2009). Nutrient imbalances in agricultural development. Science 324: 1519-1520.

Walley, F.L., Tomm, G.O., Matus, A. et al. (1996). Allocation and cycling of nitrogen in an alfalfa-bromegrass sward. Agron. J. 88: 834-843.

Watson, C.J., Jordan, C., Lennox, S.D. et al. (2000). Inorganic nitrogen in drainage water from grazed grassland in Northern Ireland. J. Environ. Qual. 29: 225-232.

Wedin, D.A. (1995). Species, nitrogen and grassland dynamics: the constraints of stuff. In: Linking Species and Ecosystems (eds. C. Jones and J.H. Lawton), 253-262. New York: Chapman and Hall.

Wedin, D.A. and Tilman, D. (1996). Influence of nitrogen loading and species composition on the carbon balance of grasslands. Science 274: 1720-1723.

Whitehead, D.C. (2000). Nutrient Elements in Grasslands: Soil-Plant-Animal Relationships. Wallingford, Oxon: CABI Publishing.

Wilkinson, A., Hill, P.W., Vaieretti, M.V. et al. (2015). Challenging the paradigm of nitrogen cycling: no evidence of in situ resource portioning by coexisting plant species in grasslands of contrasting fertility. Ecol. Evol. 5: 275-287.

Wood, C.W., Moore, P.A., Joern, B.C. et al. (2012). Nutrient management on pastures and haylands. In: Conservation Outcomes from Pastureland and Hayland Practices: Assessment, Recommendations, and Knowledge Gaps (ed. C.J. Nelson), 257-314. Lawrence, KS: Allen Press. 